\title{
Servqual dan Conjoint Analysis Dalam House of Quality Untuk Layanan Ojek Online
}

\author{
Desrina Yusi Irawati ${ }^{1 *}$, Octavia Ezrani ${ }^{2}$ \\ Teknik Industri, Teknik, Universitas Katolik Darma Cendika \\ Jl. Ir. H. Soekarno No.201, (031) 5946482/ (031) 5939625 \\ *Korespondensi penulis, surel: desrina.yusi@gmail.com
}

\begin{abstract}
One of the transportation services that need quality improvement is an online motorcycle taxis. Integration Servqual and conjoint analysis in QFD process can determine the attributes of consumer needs, and technical response as an effort to improve the service motorcycle taxi online. The result of attributes combination of motorcycle taxi online service as a whole according to customer requirement are the attention of motorcycle taxi online, information system (application), waiting for the time of arrival, completeness of attribute while driving, as well as security and safety guarantee. From the result of $Q F D$, the overall technical response that needs to be done to reach customer needs is online facility to absorb customer feedback, longer service period, and improvement of communication procedure with customers. It is formed by two segments of the customers of motorcycle taxi online namely the segment of empathy and responsiveness.
\end{abstract}

Keywords: Servqual, House of Quality, dan conjoint analysis

\begin{abstract}
Abstrak
Salah satu layanan transportasi yang perlu peningkatan kualitas adalah ojek online. Pada makalah ini mempertimbangkan integrasi Servqual dan conjoint analysis dalam QFD untuk menentukan atribut kebutuhan pelanggan, mengidentifikasi segmen pelanggan ojek online, dan respons teknis sebagai usaha memperbaiki pelayanan ojek online. Hasil kombinasi atribut layanan ojek online secara keseluruhan sesuai kebutuhan pelanggan adalah perhatian ojek online, sistem informasi (aplikasi), waktu tunggu kedatangan, kelengkapan atribut saat berkendara, serta jaminan keamanan dan keselamatan. Secara keseluruhan respons teknis yang perlu dilakukan untuk mencapai kebutuhan pelanggan adalah penambahan fasilitas pengaduan, penambahan waktu operasional, dan perbaikan tata cara komunikasi dengan pelanggan. Terbentuk dua segmen pelanggan transportasi ojek online yaitu segmen empati dan keresponsifan.
\end{abstract}

Kata kunci: Servqual, House of Quality, dan conjoint analysis

\section{Pendahuluan}

Fenomena Transportasi Berbasis Online (TBO) merupakan fenomena sharing economy di mana pemilik sumber daya seperti kendaraan maupun tenaga manusia dapat memberikan akses sementara atas sumber daya yang dimiliki kepada pelanggan. Peranan dari perusahaan TBO adalah sebagai perantara dalam menyediakan platform marketplace yang mempertemukan pemilik sumber daya tersebut dengan pelanggan. Dalam siklus transportasi perkotaan, TBO mempunyai peranan yang penting. Tarif layanan TBO dirasakan jauh lebih murah dibandingkan dengan jasa transportasi konvensional serta aksesnya tidak terikat oleh waktu dan tempat. Namun, penggunaan TBO juga memiliki beberapa kekurangan. Hal ini terlihat dari beberapa keluhan yang 
sering terjadi dalam penggunaan TBO (Grab dan Gojek), yaitu pengemudi yang membatalkan pesanan, informasi dalam pelayanan angkutan yang sering error serta keamanan dalam berkendara yang masih minim. Perusahaan bidang jasa transportasi online harus mengetahui keinginan dan kebutuhan pelanggan, sehingga dapat memberikan pelayanan terbaik. Organisasi sektor jasa perlu menawarkan kualitas agar organisasinya dapat bertahan layanan. Perusahaan jasa mencoba untuk mempertahankan pelanggan mereka dengan menyediakan layanan berkualitas [1]. Metode Servqual (Service and Quality) merupakan metode yang digunakan untuk mengetahui kriteria - kriteria kualitas pelayanan berdasarkan gap yang terjadi antara persepsi dan harapan pelanggan. Kualitas pelayanan jasa dapat dilihat dari lima dimensi yaitu bukti langsung (tangible), keandalan (reliability), ketanggapan (responsiveness), jaminan (assurance) dan empati (empathy) [2].

Atribut-atribut dari hasil pengukuran Servqual digunakan sebagai voice of customer untuk mendefinisikan customer need pada Quality Function Deployment (QFD). QFD merupakan metode terstruktur yang digunakan dalam proses perencanaan dan pengembangan produk/jasa untuk menetapkan spesifikasi kebutuhan dan keinginan konsumen, serta mengevalusi secara sistematis kapabilitas suatu produk / jasa dalam memenuhi kebutuhan dan keinginan konsumen [3]. Kekurangan QFD adalah sulit membedakan beragam kebutuhan konsumen yang bertentangan dan sulit memenuhi kebutuhan konsumen yang berbeda kelompok [4]. Untuk melengkapi proses Servqual dalam QFD, pada penelitian ini mengombinasikan dengan conjoint analysis. Conjoint analysis adalah teknik untuk mengukur trade-off guna menganalisis respons survei tentang keinginan dan tujuan konsumen dalam membeli suatu produk atau jasa [5]. Kelebihan utama dari conjoint analysis dengan metode yang lain adalah metode ini mampu membentuk stimuli dari atribut produk yang multi level dan mengatur atribut produk sesuai dengan tingkatnya. Tujuan utama dari integrasi Servqual dan conjoint analysis adalah mengetahui bagaimana pelanggan bersedia mengorbankan atribut dan level dari lima kriteria Servqual terhadap atribut lainnya. Penelitian terdahulu yang pernah ada, mereka sudah menggunakan integrasi conjoint analysis dan QFD, namun lingkup penelitian mereka hanya pada pengembangan produk[6-9].

Objek amatan pada penelitian ini adalah layanan transportasi yaitu ojek online (Gojek dan Grab). Pemilihan ojek online didasarkan atas pemikiran bahwa ojek online menjadi kebutuhan transportasi masa kini dan ojek online bukan jenis jasa kustomisasi. Hal ini dapat menjadi alasan dilakukan pendekatan conjoint analysis terkait segmentasi pasar. Segmen yang terbentuk diharapkan mewakili kebutuhan konsumen yang bervariasi. Sebelumnya penelitian tentang kualitas layanan transportasi pernah dilakukan. Penelitian tersebut menganalisis pengaruh kualitas layanan bus Trans Jakarta terhadap kepuasan konsumen. Hasil dari penelitiannya adalah bahwa ada pengaruh kualitas pelayanan terhadap pengguna jasa Trans Jakarta Busway Koridor 2 DKI Jakarta. Metode yang digunakan dalam penelitian tersebut adalah regresi [10]. Pernah ada penelitian mengenai integrasi Servqual dan QFD untuk meningkatkan kualitas layanan angkutan massa Trans Jogja. Penelitian-nya bertujuan untuk mengidentifikasi atribut-atribut layanan bus patas Trans Jogja yang sesuai dengan keinginan dan kebutuhan penumpang serta memberikan rekomendasi peningkatan dan pengembangan untuk memperbaiki kualitas layanan bus patas Trans Jogja. Dari hasil penelitian diperoleh 13 karakteristik kualitas layanan jasa PT. Jogja Tugu Trans (JTT) yang diinginkan oleh penumpang [11].

Beberapa penelitian terdahulu yang telah dilakukan menunjukkan kekurangan dari penelitian-penelitian tersebut adalah belum mampu mengidentifikasi atribut pelayanan transportasi ojek online yang multilevel dan memunculkan kekaburan 
persepsi pelanggan. Sehingga pada penelitian ini akan dilakukan integrasi Servqual dan conjoint analysis dalam QFD untuk mengetahui preferensi pelanggan ojek online yang multilevel serta melihat kebutuhan pelanggan dalam suatu segmen berdasarkan preferences segmentation. Preferences segmentation dilakukan sebagai upaya untuk tetap dapat bertahan di era kustomisasi [12]. Pada penelitian ini mempertimbangkan nilai utilitas level kriteria layanan pada penentuan nilai kepentingan relatif dari technical response sehingga technical response setiap kombinasi layanan di setiap segmen dan secara keseluruhan dapat diketahui secara jelas. Penelitian ini mengidentifikasi bagaimana metode conjoint analysis diterapkan di bidang jasa guna meningkatkan kualitas pelayanan transportasi ojek online yang sebelumnya belum pernah dipublikasikan.

\section{Metode Penelitian}

\subsection{Identifikasi Karakteristik Pelayanan Transportasi}

Karakteristik dan penentuan atribut pelayanan transportasi ojek online diperoleh dari internet, dan literature dari beberapa jurnal. Dasar yang digunakan untuk menentukan atribut pelayanan transportasi ojek online dalam penelitian ini adalah dengan menggunakan teori Servqual. Dalam penelitian ini menggunakan 5 atribut, masing-masing atribut terdiri dari beberapa level sehingga total 12 level pelayanan transportasi ojek online. Hal ini sesuai syarat metode conjoint analysis, atribut maksimal yang diizinkan adalah 9 atribut [13].

\subsection{Penyusunan Kombinasi Atribut Pelayanan Transportasi}

Penyusunan kombinasi adalah penentuan kombinasi atribut pelayanan yang nantinya akan ditanyakan kepada responden dalam bentuk kuesioner. Atribut pelayanan yang digunakan adalah kriteria pelayanan dari metode Servqual sesuai hasil sub-bab 2.1. Pada traditional conjoint analysis banyaknya kombinasi yang terbentuk menggunakan metode full-combination. Jumlah kombinasi yang harus disediakan 1,5 sampai 2 kali jumlah minimum yang harus tersedia untuk mengantisipasi penyimpangan dari konsep conjoint analysis [14]. Hasil kombinasi yang terbentuk dari desain fractional factorial selanjutnya dinilai oleh 110 responden dalam bentuk kuesioner. Dasar pengambilan jumlah sampel berdasarkan teori Bernoulli dengan rumus pada Persamaan 1.

$n=\frac{\left(Z_{\propto / 2}\right)^{2} . P . q}{e^{2}}$

\subsection{Pengolahan Data Dengan Conjoint Analysis}

Hasil survei penyebaran kuesioner selanjutnya diolah menggunakan SPSS untuk mendapatkan nilai utility untuk masing-masing level. Sebelumnya dilakukan evaluasi goodness of fit terhadap nilai korelasi yang dimiliki. Pengukuran goodness of fit dapat diketahui dari nilai korelasi Pearson's R dan Kendall's Tau. Supaya keakuratan dan konsistensi responden dalam mengisi kuesioner tetap terjaga maka batas minimum nilai signifikansi $p$-value $<0,05$. Jika nilai korelasi lebih besar dari 0,05 maka data belum layak untuk dianalisis dan perlu dilakukan pengecekan ulang di tahap sebelumnya.

Untuk mengidentifikasi preferences segmentation konsumen maka dilakukan cluster analysis. Cluster analysis dilakukan dengan menggunakan $K$-means. Dari $K$ means diperoleh kelompok sesuai dengan nilai kepentingan dari atribut pelayanan 
transportasi. Selanjutnya adalah melakukan conjoint analysis untuk setiap segmen sehingga diperoleh nilai utilitas dan nilai kepentingan relatif setiap segmen.

\subsection{House of Quality (HoQ)}

Dalam membuat HoQ tahapan pertama yang perlu dilakukan adalah menentukan customer needs. Customer needs diperoleh dari tahap conjoint analysis, yaitu kombinasi atribut pelayanan transportasi ojek online. Dari proses conjoint analysis secara keseluruhan dan setiap segmen, diperoleh nilai utilitas dan nilai kepentingan relatif. Nilai tersebut masuk pada planning matrix.

Dari nilai utilitas dan nilai kepentingan relatif yang telah diperoleh, perusahaan berusaha merencanakan kegiatan yang akan dilakukan dalam mengembangkan pelayanan, kegiatan tersebut masuk pada tahap technical response. Technical response didapatkan dengan hasil wawancara dengan perwakilan pihak perusahaan transportasi ojek online. Ketika customer needs dan technical response diperoleh, tahap selanjutnya adalah menentukan bobot pada relationship matrix. Pembobotan diterjemahkan dengan nilai 9 (kuat), 3 (sedang), dan 1 (lemah).

Untuk menggambarkan korelasi antar masing-masing technical response maka perlu tahap pengisian technical correlation matrix. Nilai hubungan tersebut dapat disimbolkan sebagai berikut: $\sqrt{ } \sqrt{ }$ (hubungan positif kuat), $\sqrt{ }$ (hubungan positif medium), kosong (tidak ada hubungan). Tahap terakhir yang dilakukan pada tahap HoQ adalah menghitung kepentingan relatif setiap segmen dari technical response.

\section{Hasil dan Pembahasan}

\subsection{Identifikasi Karakteristik Kombinasi Atribut}

Atribut pelayanan transportasi ojek online yang digunakan dalam penelitian ini diambil dari lima dimensi kualitas pelayanan yaitu bukti langsung (tangible), keandalan (reliability), ketanggapan (responsiveness), jaminan (assurance) dan empati (empathy) [15]. Setiap atribut dan level pelayanan transportasi ojek online dari hasil studi literatur disajikan pada Tabel 1. Atribut dan level pelayanan transportasi ojek online selanjutnya dikombinasikan menghasilkan kombinasi yang dapat dilihat pada Tabel 2. Penjelasan untuk masing-masing level adalah sebagai berikut: (1) Kelengkapan atribut: ketersediaan helm, masker, shower cap, jas hujan. (2) Kondisi motor: kelayakan kondisi motor ketika dikendarai (terpasang 2 spion, injakan kaki, pegangan tangan,lampu motor, lampu sen, dll). (3) Keramahan driver: cara berkomunikasi yang baik antara driver dalam menanggapi konsumen. (4) Perhatian petugas: perhatian petugas kantor/driver terhadap keluhan dari konsumen. (5) Fasilitas pengaduan bila ada keluhan: fasilitas pengaduan yang mudah dihubungi dan respons cepat. (6) Waktu menunggu antara kedatangan: respons kedatangan driver setelah menerima pesanan. (7) Keahlian dalam mengemudi: driver ahli dalam mengemudi ditunjukkan dengan kepemilikan SIM dan menguasai rute jalan (tata tertib lalu lintas). (8) Sistem informasi pelayanan: kelengkapan data informasi driver (nama, no HP, foto pengemudi). (9) Informasi (aplikasi) tentang pelayanan angkutan: kemudahan dalam penggunaan tools di aplikasi. (10) Jam operasional: waktu operasional angkutan 24 jam. (11) Jaminan keamanan dan keselamatan: adanya jaminan keamanan dan keselamatan dari perusahaan (asuransi kematian, asuransi kecelakaan). (12) Jaminan privasi data konsumen: adanya jaminan privasi data konsumen agar data konsumen tidak tersebar, diperjual-belikan, dan di salahgunakan. 


\subsection{Pengolahan Statistik Deskriptif}

Sampel dihitung berdasarkan persamaan (1). Hasil perhitungan sampel diperoleh 110 responden. Dari karakteristik 110 responden hasil survei, dapat diperoleh data demografi seperti disajikan pada Gambar 1.

Tabel 1 Atribut dan level

\begin{tabular}{ccc}
\hline Atribut & Level & Kode \\
\hline Bukti Fisik & Kelengkapan atribut & $\mathrm{A}$ \\
(Tangibles) & Kondisi motor & $\mathrm{B}$ \\
& Keramahan driver & $\mathrm{C}$ \\
Empati (Empathy) & Perhatian petugas & $\mathrm{D}$ \\
& Fasilitas pengaduan bila ada keluhan & $\mathrm{E}$ \\
Keandalan & Waktu menunggu antara kedatangan & $\mathrm{F}$ \\
(Reliability) & Keahlian dalam mengemudi & $\mathrm{G}$ \\
Keresponsifan & Sistem informasi pelayanan & $\mathrm{H}$ \\
(Responsiveness) & Informasi tentang pelayanan angkutan & $\mathrm{I}$ \\
& Jam operasional & \\
Jaminan (Assurance) & Jaminan keamanan dan keselamatan & \\
\hline
\end{tabular}
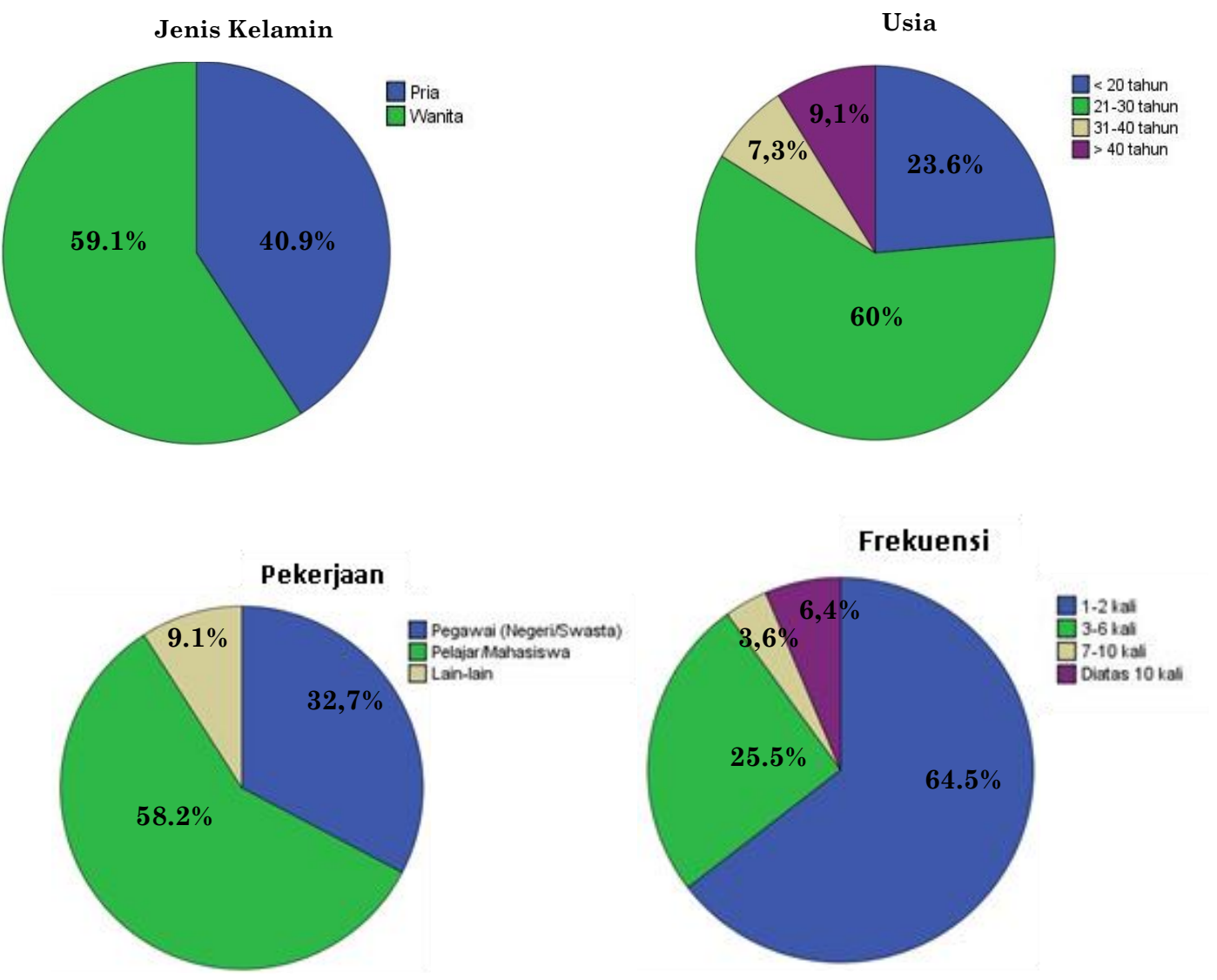

Gambar 1 Pie-chart data responden 
Tabel 2 Kombinasi atribut pelayanan transportasi ojek online

\begin{tabular}{|c|c|c|c|c|c|}
\hline $\begin{array}{l}\text { Card } \\
\text { ID }\end{array}$ & $\begin{array}{l}\text { Bukti_fisik } \\
\text { (Tangibles) }\end{array}$ & $\begin{array}{c}\text { Empati } \\
\text { (Empathy) }\end{array}$ & $\begin{array}{l}\text { Keandalan } \\
\text { (Reliability) }\end{array}$ & $\begin{array}{l}\text { Keresponsifan } \\
\text { (Responsiveness) }\end{array}$ & $\begin{array}{c}\text { Jaminan } \\
\text { (Assurance) }\end{array}$ \\
\hline 1 & Kondisi motor & $\begin{array}{l}\text { Fasilitas } \\
\text { pengaduan bila } \\
\text { ada keluhan }\end{array}$ & $\begin{array}{l}\text { Keahlian dalam } \\
\text { mengemudi }\end{array}$ & Jam operasional & $\begin{array}{l}\text { Jaminan } \\
\text { keamanan dan } \\
\text { keselamatan }\end{array}$ \\
\hline 2 & $\begin{array}{l}\text { Kelengkapan } \\
\text { atribut }\end{array}$ & $\begin{array}{l}\text { Keramahan } \\
\text { driver }\end{array}$ & $\begin{array}{l}\text { Keahlian dalam } \\
\text { mengemudi }\end{array}$ & $\begin{array}{l}\text { Sistem informasi } \\
\text { pelayananan }\end{array}$ & $\begin{array}{l}\text { Jaminan privasi } \\
\text { data konsumen }\end{array}$ \\
\hline 3 & $\begin{array}{l}\text { Kelengkapan } \\
\text { atribut }\end{array}$ & $\begin{array}{l}\text { Fasilitas } \\
\text { pengaduan bila } \\
\text { ada keluhan }\end{array}$ & $\begin{array}{l}\text { Waktu } \\
\text { menunggu antar } \\
\text { kedatangan }\end{array}$ & $\begin{array}{l}\text { Sistem informasi } \\
\text { pelayanan }\end{array}$ & $\begin{array}{l}\text { Jaminan privasi } \\
\text { data konsumen }\end{array}$ \\
\hline 4 & $\begin{array}{l}\text { Kelengkapan } \\
\text { atribut }\end{array}$ & $\begin{array}{l}\text { Fasilitas } \\
\text { pengaduan bila } \\
\text { ada keluhan }\end{array}$ & $\begin{array}{l}\text { Keahlian dalam } \\
\text { mengemudi }\end{array}$ & $\begin{array}{l}\text { Informasi tentang } \\
\text { pelayanan } \\
\text { angkutan }\end{array}$ & $\begin{array}{l}\text { Jaminan } \\
\text { keamanan dan } \\
\text { keselamatan }\end{array}$ \\
\hline 5 & Kondisi motor & $\begin{array}{l}\text { Keramahan } \\
\text { driver }\end{array}$ & $\begin{array}{l}\text { Waktu } \\
\text { menunggu antar } \\
\text { kedatangan }\end{array}$ & $\begin{array}{l}\text { Informasi tentang } \\
\text { pelayanan } \\
\text { angkutan }\end{array}$ & $\begin{array}{l}\text { Jaminan } \\
\text { keamanan dan } \\
\text { keselamatan }\end{array}$ \\
\hline 6 & Kondisi motor & $\begin{array}{l}\text { Keramahan } \\
\text { driver }\end{array}$ & $\begin{array}{l}\text { Keahlian dalam } \\
\text { mengemudi }\end{array}$ & $\begin{array}{l}\text { Informasi tentang } \\
\text { pelayanan } \\
\text { angkutan }\end{array}$ & $\begin{array}{l}\text { Jaminan privasi } \\
\text { data konsumen }\end{array}$ \\
\hline 7 & Kondisi motor & $\begin{array}{l}\text { Fasilitas } \\
\text { pengaduan bila } \\
\text { ada keluhan }\end{array}$ & $\begin{array}{l}\text { Waktu } \\
\text { menunggu antar } \\
\text { kedatangan }\end{array}$ & $\begin{array}{l}\text { Sistem informasi } \\
\text { pelayanan }\end{array}$ & $\begin{array}{l}\text { Jaminan privasi } \\
\text { data konsumen }\end{array}$ \\
\hline 8 & $\begin{array}{l}\text { Kelengkapan } \\
\text { atribut }\end{array}$ & $\begin{array}{l}\text { Keramahan } \\
\text { driver }\end{array}$ & $\begin{array}{l}\text { Keahlian dalam } \\
\text { mengemudi }\end{array}$ & Jam operasional & $\begin{array}{l}\text { Jaminan privasi } \\
\text { data konsumen }\end{array}$ \\
\hline 9 & Kondisi motor & $\begin{array}{l}\text { Perhatian } \\
\text { petugas }\end{array}$ & $\begin{array}{l}\text { Keahlian dalam } \\
\text { mengemudi }\end{array}$ & $\begin{array}{l}\text { Sistem informasi } \\
\text { pelayanan }\end{array}$ & $\begin{array}{l}\text { Jaminan } \\
\text { keamanan dan } \\
\text { keselamatan }\end{array}$ \\
\hline 10 & Kondisi motor & $\begin{array}{l}\text { Keramahan } \\
\text { driver }\end{array}$ & $\begin{array}{l}\text { Keahlian dalam } \\
\text { mengemudi }\end{array}$ & $\begin{array}{l}\text { Sistem informasi } \\
\text { pelayanan }\end{array}$ & $\begin{array}{l}\text { Jaminan privasi } \\
\text { data konsumen }\end{array}$ \\
\hline 11 & $\begin{array}{l}\text { Kelengkapan } \\
\text { atribut }\end{array}$ & $\begin{array}{l}\text { Perhatian } \\
\text { petugas }\end{array}$ & $\begin{array}{l}\text { Waktu } \\
\text { menunggu antar } \\
\text { kedatangan }\end{array}$ & $\begin{array}{l}\text { Informasi tentang } \\
\text { pelayanan } \\
\text { angkutan }\end{array}$ & $\begin{array}{l}\text { Jaminan privasi } \\
\text { data konsumen }\end{array}$ \\
\hline 12 & $\begin{array}{l}\text { Kelengkapan } \\
\text { atribut }\end{array}$ & $\begin{array}{l}\text { Keramahan } \\
\text { driver }\end{array}$ & $\begin{array}{l}\text { Waktu } \\
\text { menunggu antar } \\
\text { kedatangan }\end{array}$ & $\begin{array}{l}\text { Sistem informasi } \\
\text { pelayanan }\end{array}$ & $\begin{array}{l}\text { Jaminan } \\
\text { keamanan dan } \\
\text { keselamatan }\end{array}$ \\
\hline 13 & $\begin{array}{l}\text { Kelengkapan } \\
\text { atribut }\end{array}$ & $\begin{array}{l}\text { Keramahan } \\
\text { driver }\end{array}$ & $\begin{array}{l}\text { Waktu } \\
\text { menunggu antar } \\
\text { kedatangan }\end{array}$ & Jam operasional & $\begin{array}{l}\text { Jaminan } \\
\text { keamanan dan } \\
\text { keselamatan }\end{array}$ \\
\hline 14 & Kondisi motor & $\begin{array}{l}\text { Keramahan } \\
\text { driver }\end{array}$ & $\begin{array}{l}\text { Waktu } \\
\text { menunggu antar } \\
\text { kedatangan }\end{array}$ & $\begin{array}{l}\text { Sistem informasi } \\
\text { pelayanan }\end{array}$ & $\begin{array}{l}\text { Jaminan } \\
\text { keamanan dan } \\
\text { keselamatan }\end{array}$ \\
\hline 15 & Kondisi motor & $\begin{array}{l}\text { Perhatian } \\
\text { petugas }\end{array}$ & $\begin{array}{l}\text { Waktu } \\
\text { menunggu antar } \\
\text { kedatangan }\end{array}$ & Jam operasional & $\begin{array}{l}\text { Jaminan privasi } \\
\text { data konsumen }\end{array}$ \\
\hline 16 & $\begin{array}{l}\text { Kelengkapan } \\
\text { atribut }\end{array}$ & $\begin{array}{l}\text { Perhatian } \\
\text { petugas }\end{array}$ & $\begin{array}{l}\text { Keahlian dalam } \\
\text { mengemudi }\end{array}$ & $\begin{array}{l}\text { Sistem informasi } \\
\text { pelayanan }\end{array}$ & $\begin{array}{l}\text { Jaminan } \\
\text { keamanan dan } \\
\text { keselamatan }\end{array}$ \\
\hline
\end{tabular}

\subsection{Hasil Pengolahan Conjoint Analysis}

Hasil pengolahan proses conjoint analysis dapat dilihat pada Tabel 3 , Tabel 4, dan Tabel 5 . Pada penelitian ini, data yang dihasilkan dari kuesioner adalah data dengan skala ranking, sehingga untuk melakukan analisis goodness of fit dilakukan 
dengan nilai korelasi Kendall's Tau. Hasil pada Tabel 3 , diketahui bahwa prediksi utilitas dengan utilitas aktual saling berkorelasi positif sebesar 0,735 dan 0,583, dan memiliki $p$-value (signifikansi) masing-masing sebesar 0.001 dan 0.001 lebih kecil dari $=$ 0,05 (derajat signifikansi). Hal ini membuktikan terdapat ketepatan dalam memprediksi (Predictive Accuracy), ada korelasi yang kuat antara hasil estimasi dengan nilai preferensi yang sebenarnya

Tabel 3 Correlations conjoint analysis

\begin{tabular}{llc}
\hline & \multicolumn{3}{c}{ Correlations $^{\text {a }}$} \\
& Value & Sig. \\
Pearson's R & .735 & .001 \\
$\begin{array}{llc}\text { Kendall's } \\
\text { tau }\end{array}$ & .583 & .001 \\
\hline
\end{tabular}

Hasil perhitungan nilai utilitas dapat dilihat di Tabel 4. Dari tabel tersebut diketahui bahwa setiap atribut yang terdiri dari dua level memiliki nilai utilitas yang sama dengan tanda yang berbeda yaitu negatif dan positif. Tanda positif menunjukkan bahwa level tersebut tidak diminati dibandingkan dengan yang bertanda negatif. Semakin besar nilai positif utilitas sebuah level maka level tersebut semakin tidak diminati.

Tabel 4 Nilai utilitas

\section{Utilities}

\begin{tabular}{|c|c|c|c|}
\hline & & $\begin{array}{c}\text { Utility } \\
\text { Estimate }\end{array}$ & Std. Error \\
\hline \multirow[t]{2}{*}{ Fisik } & Kelengkapan atribut & -.027 & .224 \\
\hline & Kondisi motor & .027 & .224 \\
\hline \multirow[t]{3}{*}{ Empati } & Keramahan driver & .229 & .299 \\
\hline & Perhatian petugas & -.669 & .351 \\
\hline & $\begin{array}{l}\text { Fasilitas pengaduan } \\
\text { bila ada keluhan }\end{array}$ & .897 & .351 \\
\hline \multirow[t]{2}{*}{ Keandalan } & $\begin{array}{l}\text { Waktu menunggu } \\
\text { antar kedatangan }\end{array}$ & -.283 & .224 \\
\hline & $\begin{array}{l}\text { Keahlian dalam } \\
\text { mengemudi }\end{array}$ & .283 & .224 \\
\hline \multirow[t]{3}{*}{ Keresponsifan } & $\begin{array}{l}\text { Sistem informasi } \\
\text { pelayanan }\end{array}$ & -.250 & .299 \\
\hline & $\begin{array}{l}\text { Informasi tentang } \\
\text { pelayanan angkutan }\end{array}$ & .290 & .351 \\
\hline & Jam operasional & -.040 & .351 \\
\hline \multirow[t]{2}{*}{ Asuransi } & $\begin{array}{l}\text { Jaminan keamanan } \\
\text { dan keselamatan }\end{array}$ & -.086 & .224 \\
\hline & $\begin{array}{c}\text { Jaminan privasi data } \\
\text { konsumen }\end{array}$ & .086 & .224 \\
\hline (Constant) & & 8.620 & .248 \\
\hline
\end{tabular}


Setelah nilai utilitas setiap level diperoleh maka akan diketahui tingkat kepentingan setiap atribut. Dari Tabel 5 diketahui bahwa nilai kepentingan relatif tertinggi diantara atribut yang lain adalah atribut empati $(31,598 \%)$, selanjutnya keresponsifan (27,593\%), keandalan (15,179\%), fisik (13,406\%), serta jaminan (12,224\%). Jika melihat kembali nilai utilitas rata-rata setiap level pada Tabel 4, maka level empati yang menjadi prioritas responden adalah perhatian petugas, dengan nilai utilitas negatif terbesar diantara level atribut lainnya $(-0,669)$. Secara keseluruhan urutan level prioritas responden berdasarkan nilai kepentingan relatif dan utilitas adalah perhatian petugas ojek online, sistem informasi (aplikasi) pelayanan, waktu menunggu antar kedatangan, kelengkapan atribut motor, dan jaminan keamanan dan keselamatan.

Tabel 5 Important value

\begin{tabular}{lr}
\hline Importance Values \\
Fisik & 13.406 \\
Empati & 31.598 \\
Keandalan & 15.179 \\
Keresponsifan & 27.593 \\
Asuransi & 12.224 \\
\hline
\end{tabular}

\subsection{Hasil Pengolahan Conjoint Analysis Setiap Cluster}

Pembentukan cluster berguna untuk melihat preferences segments, yaitu pengelompokkan yang didasarkan kepada harapan atau respons konsumen dari suatu produk atau jasa. Conjoint analysis setiap segmen dilakukan untuk medapatkan nilai kepentingan serta utilitas setiap segmen yang telah terbentuk pada tahap cluster analysis. Pengelompokkan dilakukan dengan 2 metode yaitu metode K-means. K-means memiliki keunggulan yaitu analisa sampel lebih besar, memiliki sedikit kelemahan pada data outlier, ukuran jarak, dan variabel yang tidak relevan. Nilai tingkat kepentingan dan utilitas tiap segmen hasil conjoint analysis dapat dililhat pada Tabel 6.

Berdasarkan Tabel 6 dapat diketahui pada cluster 1 merupakan cluster keresponsifan (responsiveness) artinya keresponsifan menjadi preferensi utama responden ketika menggunakan pelayanan transportasi ojek online. Hal ini dapat dilihat dari nilai kepentingan yang paling besar diantara nilai kepentingan atribut lainnya yaitu sebesar 30,227\%. Kombinasi pelayanan transportasi ojek online terbaik berdasarkan nilai utilitas dan kepentingan pada cluster 1 adalah sistem informasi (aplikasi) pelayanan yang baik, keramahan driver, kelengkapan atribut, waktu menunggu antar kedatangan, dan terdapat jaminan keamanan dan keselamatan.

Cluster 2 merupakan cluster empati (empathy) artinya dengan nilai kepentingan atribut sebesar 35,965\%. Kombinasi pelayanan transportasi ojek online terbaik berdasarkan nilai utilitas dan kepentingan pada cluster 2 adalah keramahan driver, sistem informasi (aplikasi) pelayanan yang baik, waktu menunggu antar kedatangan, terdapat jaminan keamanan dan keselamatan, dan kelengkapan atribut. 
Tabel 6 Nilai kepentingan dan utilitas antar cluster

\begin{tabular}{|c|c|c|c|c|c|}
\hline \multirow{2}{*}{ Atribut } & \multirow{2}{*}{ Level } & \multicolumn{2}{|c|}{ Nilai Kepentingan } & \multicolumn{2}{|c|}{ Utilitas } \\
\hline & & Clus. 1 & Clus. 2 & Clus. 1 & Clus. 2 \\
\hline \multirow{2}{*}{$\begin{array}{l}\text { Bukti Fisik } \\
\text { (Tangibles) }\end{array}$} & Kelengkapan atribut & \multirow{2}{*}{15,265} & \multirow{2}{*}{11,255} & $-0,119$ & 0,078 \\
\hline & Kondisi motor & & & 0,119 & $-0,078$ \\
\hline \multirow{3}{*}{ Empati (Empathy) } & Keramahan driver & \multirow{3}{*}{27,824} & \multirow{3}{*}{35,965} & $-0,291$ & $-0,157$ \\
\hline & $\begin{array}{l}\text { Perhatian petugas ojek } \\
\text { online }\end{array}$ & & & 0,33 & $-1,824$ \\
\hline & Pengaduan keluhan & & & $-0,039$ & 1,980 \\
\hline \multirow[t]{2}{*}{$\begin{array}{l}\text { Keandalan } \\
\text { (Reliability) }\end{array}$} & $\begin{array}{l}\text { Waktu menunggu antar } \\
\text { kedatangan } \\
\text { Keahlian dalam }\end{array}$ & \multirow[t]{2}{*}{15,245} & \multirow[t]{2}{*}{15,101} & $-0,112$ & $-0,480$ \\
\hline & mengemudi & & & 0,112 & 0,480 \\
\hline \multirow{3}{*}{$\begin{array}{l}\text { Keresponsifan } \\
\text { (Responsiveness) }\end{array}$} & $\begin{array}{l}\text { Sistem informasi (aplikasi) } \\
\text { pelayanan }\end{array}$ & \multirow{3}{*}{30,227} & \multirow{3}{*}{24,546} & $-0,099$ & $-0,425$ \\
\hline & $\begin{array}{l}\text { Informasi tentang } \\
\text { pelayanan angkutan }\end{array}$ & & & $-0,224$ & 0,884 \\
\hline & Jam operasional & & & 0,323 & $-0,459$ \\
\hline \multirow[t]{2}{*}{$\begin{array}{l}\text { Jaminan } \\
\text { (Assurance) }\end{array}$} & $\begin{array}{l}\text { Jaminan keamanan dan } \\
\text { keselamatan } \\
\text { Jaminan privasi data }\end{array}$ & \multirow[t]{2}{*}{11,438} & \multirow[t]{2}{*}{13,133} & $-0,081$ & $-0,930$ \\
\hline & konsumen & & & 0,081 & 0,093 \\
\hline
\end{tabular}

\subsection{Analisis House of Quality \\ 3.4.1. Customer Need}

Atribut conjoint analysis dari lima kriteria Servqual akan menjadi masukan pada HoQ bagian customer needs. Atribut dan level yang terpilih adalah sebagai berikut: (1) Bukti fisik (Tangibles): Bukti fisik terdiri dari kelengkapan atribut penumpang saat berkendara (helm, masker, shower cap, jas hujan.) dan kondisi motor atau kelayakan kondisi motor ketika dikendarai (Terpasang 2 spion, injakan kaki, pegangan tangan,lampu motor, lampu sen). (2) Empati (Empathy): Empati terdiri dari keramahan driver (cara berkomunikasi antara driver dalam menanggapi konsumen), perhatian petugas terhadap keluhan dari pelanggan, dan tersedianya fasilitas pengaduan. (3) Keandalan (Reliability): Keandalan terdiri dari waktu menunggu antara kedatangan (respons kedatangan driver setelah menerima pesanan) dan keahlian dalam mengemudi dibuktikan dengan kelengkapan SIM serta menguasai rute jalan. (4) Keresponsifan (Responsiveness): Keresponsifan terdiri dari sistem informasi (aplikasi) pelayanan, informasi tentang pelayanan angkutan pada aplikasi, dan penambahan waktu operasional. (5) Jaminan (Assurance): Jaminan terdiri dari jaminan keamanan dan keselamatan serta jaminan privasi data konsumen (data konsumen tidak tersebar atau diperjual-belikan).

\subsubsection{Planning Matrix}

Penentuan prioritas atribut dilakukan atas dasar nilai kepentingan relatif yang diperoleh setiap segmen dan secara keseluruhan dari proses conjoint analysis. Nilai kepentingan relative dan utilitas yang masuk pada bagian planning matrix, seperti tertulis pada Tabel 7. Nantinya nilai kepentingan ini dihitung dengan nilai pembobotan respons teknis. 
Tabel 7 Bagian planning matrix

\begin{tabular}{|c|c|c|c|c|c|c|c|}
\hline \multirow{2}{*}{\multicolumn{2}{|c|}{ Customer needs }} & \multicolumn{3}{|c|}{ Kepentingan relatif (\%) } & \multicolumn{3}{|c|}{ Utilitas } \\
\hline & & All & Seg.1 & Seg.2 & All & Seg.1 & Seg.2 \\
\hline \multirow{2}{*}{$\begin{array}{l}\text { Bukti Fisik } \\
\text { (Tangibles) }\end{array}$} & $\begin{array}{l}\text { Kelengkapan } \\
\text { atribut }\end{array}$ & \multirow{2}{*}{13,406} & \multirow{2}{*}{15,265} & \multirow{2}{*}{11,255} & $-0,027$ & $-0,119$ & 0,078 \\
\hline & Kondisi motor & & & & 0,027 & 0,119 & $-0,078$ \\
\hline \multirow{3}{*}{$\begin{array}{l}\text { Empati } \\
\text { (Empathy) }\end{array}$} & $\begin{array}{l}\text { Keramahan } \\
\text { driver } \\
\text { Perhatian }\end{array}$ & \multirow{3}{*}{31,598} & \multirow{3}{*}{27,824} & \multirow{3}{*}{35,965} & $-0,229$ & $-0,291$ & $-0,157$ \\
\hline & $\begin{array}{l}\text { petugas ojek } \\
\text { online } \\
\text { Pengaduan }\end{array}$ & & & & $-0,669$ & 0,33 & $-1,824$ \\
\hline & keluhan & & & & 0,897 & $-0,039$ & 1,980 \\
\hline \multirow[t]{2}{*}{$\begin{array}{l}\text { Keandalan } \\
\text { (Reliability) }\end{array}$} & $\begin{array}{c}\text { Waktu } \\
\text { menunggu antar } \\
\text { kedatangan } \\
\text { Keahlian dalam }\end{array}$ & \multirow[t]{2}{*}{15,179} & \multirow[t]{2}{*}{15,245} & \multirow[t]{2}{*}{15,101} & $-0,283$ & $-0,112$ & $-0,480$ \\
\hline & mengemudi & & & & 0,283 & 0,112 & 0,480 \\
\hline \multirow{4}{*}{$\begin{array}{l}\text { Keresponsifan } \\
\text { (Responsivenes) }\end{array}$} & $\begin{array}{c}\text { Sistem informasi } \\
\text { (aplikasi) } \\
\text { pelayanan }\end{array}$ & \multirow{4}{*}{27,593} & \multirow{4}{*}{30,227} & \multirow{4}{*}{24,546} & $-0,25$ & $-0,099$ & $-0,425$ \\
\hline & $\begin{array}{l}\text { Informasi } \\
\text { tentang }\end{array}$ & & & & & & \\
\hline & angkutan & & & & 0,29 & $-0,224$ & 0,884 \\
\hline & Jam operasional & & & & $-0,04$ & 0,323 & $-0,459$ \\
\hline \multirow[t]{2}{*}{$\begin{array}{l}\text { Jaminan } \\
\text { (Assurance) }\end{array}$} & $\begin{array}{c}\text { Jaminan } \\
\text { keamanan dan } \\
\text { keselamatan } \\
\text { Jaminan privasi }\end{array}$ & \multirow[t]{2}{*}{12,224} & \multirow[t]{2}{*}{11,438} & \multirow[t]{2}{*}{13,133} & $-0,086$ & $-0,081$ & $-0,930$ \\
\hline & data konsumen & & & & 0,086 & 0,081 & 0,093 \\
\hline
\end{tabular}

\subsubsection{Technical Response}

Technical response berisi rencana kegiatan yang dilakukan perusahaan untuk melakukan perbaikan pelayanan. Hasil technical response adalah sebagai berikut: (1) Ketersediaan helm, masker, shower cap, jas hujan. (2) Terpasang 2 spion, injakan kaki, pegangan tangan,lampu motor, lampu sen. (3) Penambahan fasilitas pengaduan (kolom komentar \& no telepon). (4) Penggunaan GPS. (5) Penambahan fitur foto pengemudi terbaru. (6) Penambahan fitur foto pengemudi terbaru. (7) Pemasangan tools pada aplikasi yang mudah dipahami. (8) Penambahan waktu operasional (24 jam). (9) Ketersediaan asuransi kematian \& kecelakaan. (10) Penambahan sistem pengaman data pelanggan. (11) Perbaikan tata cara komunikasi dengan pelanggan. (12) Kelengkapan STNK \& SIM/penguasaan tata tertib lalulintas. (13) Driver menguasai rute jalan.

Pembobotan technical respons dilakukan untuk menilai seberapa besar technical response yang perlu dilakukan dalam menjawab costumer needs. Hubungan antara atribut customer needs dan technical response disusun dalam bentuk matriks, seperti Tabel 8. 
Tabel 8 Hubungan antara technical response dengan customer needs

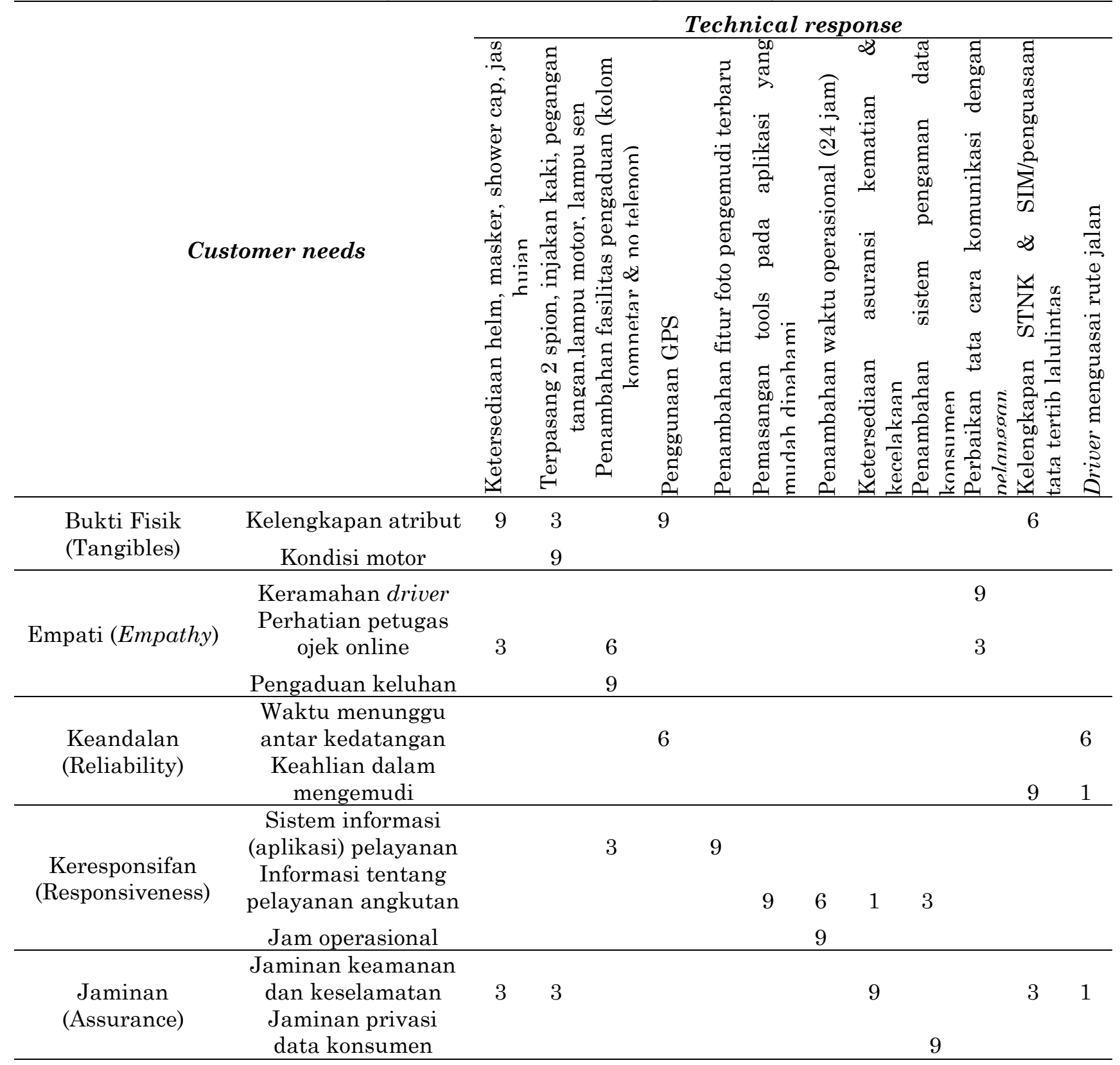

Hubungan antar technical response merupakan hubungan dan saling keterkaitan antara respons teknik. Hubungan diperoleh berdasarkan wawancara dengan pihak perusahaan. Bobot yang digunakan dalam hubungan antar respons teknik dilambangkan dengan hubungan kuat positif $(\sqrt{ } \sqrt{ })$, hubungan lemah positif $(\sqrt{ })$, dan tidak ada hubungan (kosong). Hubungan antar technical response dapat dilihat di Gambar 2. Beberapa technical response yang memiliki hubungan yang kuat adalah (1) Terpasangnya 2 spion injakan kaki, pegangan tangan,lampu motor, lampu sen menjadi hal penting karena menyangkut keselamatan berkendara. Jika hal tersebut tidak terpenuhi penumpang dapat melaporkan hal tersebut ke kantor ojek online. (2) Ketersediaan helm, masker, shower cap, jas hujan menjadi hal penting karena menyangkut keselamatan dan kenyamaan berkendara. Apabila kelengkapan tersebut tidak terpenuhi, pelanggan dapat megadukan hal tersebut. (3) Kelengkapan STNK \& SIM/penguasaan tata tertib lalulintas adalah syarat mutlak bagi pengemudi. Apabila 
pengemudi ugal-ugalan dan tidak memahami aturan lalulintas, pelanggan dapat megadukan hal tersebut ke kantor. Kolom/no telepon pengaduan penting dimiliki perusahaan sebagai cara memantau pengemudi. (4) Sebagai usaha mempermudah pengemudi menguasai rute jalan, pemasangan GPS sangat diperlukan.

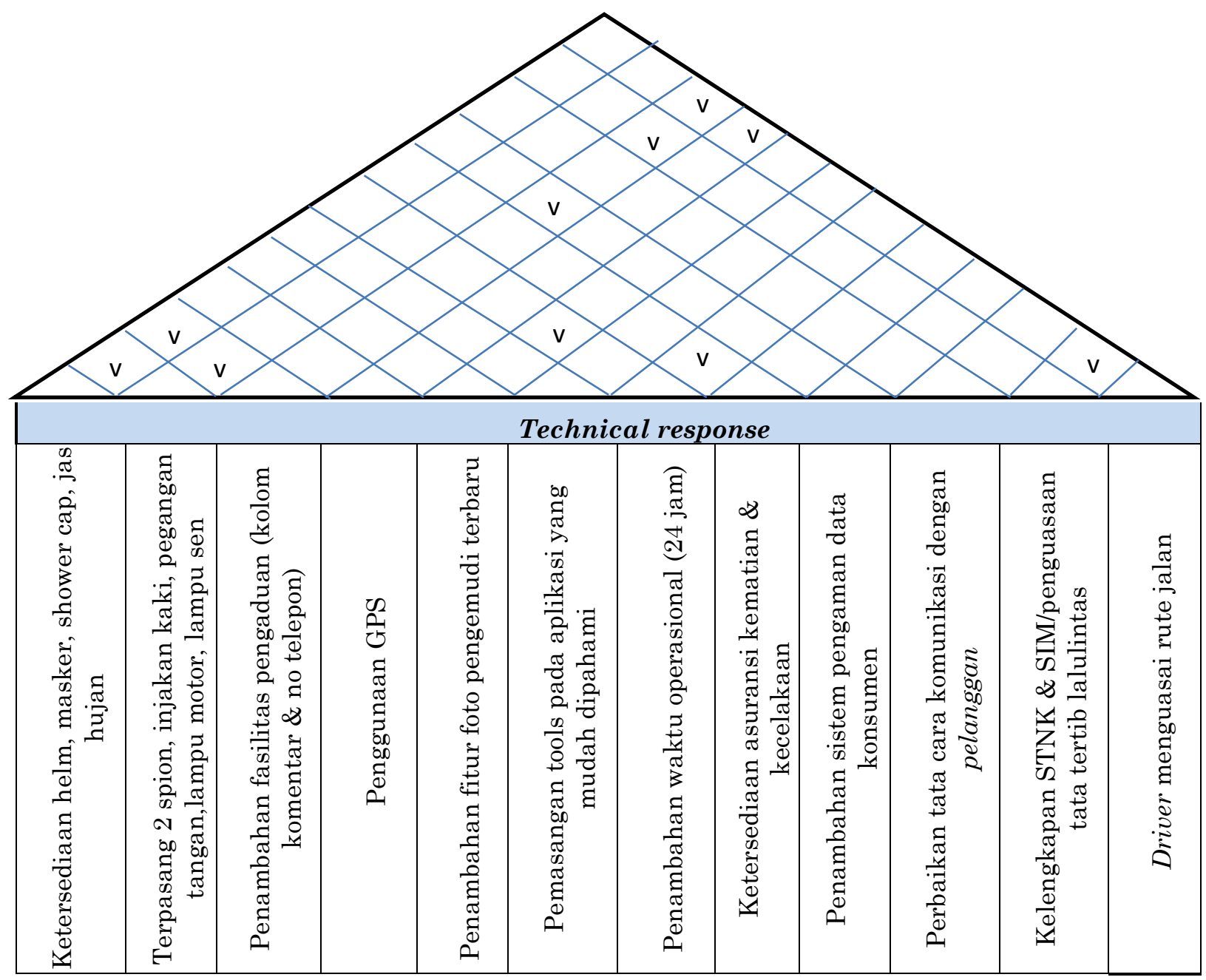

Gambar 2 Hubungan antar technical response

\subsubsection{Technical Matrix}

Persentase kepentingan relatif respons teknis merupakan suatu ukuran yang menunjukkan prioritas respons teknis yang harus mendapat perhatian perusahaan dalam kaitannya dengan perbaikan pelayanan. Technical matrix berisi bobot respons teknis secara keseluruhan dan pada setiap segmen berupa nilai persentase kepentingan relatif. Sesuai dengan Tabel 9.

Urutan technical response yang perlu dilakukan perusahaan sebagai upaya memperbaiki layanan dapat dipilih dengan batasan nilai absolut lebih besar dari nilai absolut rata-rata. Pada segmen 1 nilai absolut rata-rata adalah 263,7935 sehingga urutan technical response yang perlu dilakukan perusahaan adalah penambahan fasilitas pengaduan (kolom komentar \& no telepon), penambahan waktu operasional (24 jam), perbaikan tata cara komunikasi dengan pelanggan, pemasangan tools pada aplikasi yang mudah dipahami, dan penambahan fitur foto pengemudi terbaru. Pada segmen 2 nilai absolut rata-rata adalah 254,8351 sehingga urutan technical response 
yang perlu dilakukan perusahaan adalah penambahan fasilitas pengaduan (kolom komentar \& no telepon), penambahan waktu operasional (24 jam), dan perbaikan tata cara komunikasi dengan pelanggan. Pada segmen 2 nilai absolut rata-rata adalah 254,8351 sehingga urutan technical response yang perlu dilakukan perusahaan adalah penambahan fasilitas pengaduan (kolom komentar \& no telepon), penambahan waktu operasional (24 jam), dan perbaikan tata cara komunikasi dengan pelanggan. Secara keseluruhan, nilai absolut rata-rata adalah 267,5405 sehingga technical response yang layak dilakukan perusahaan adalah penambahan fasilitas pengaduan (kolom komentar \& no telepon), penambahan waktu operasional (24 jam), dan perbaikan tata cara komunikasi dengan pelanggan.

Tabel 9 Persentase kepentingan relatif pada technical matrix

\begin{tabular}{|c|c|c|c|c|}
\hline No. & Technical Response & Keseluruhan & Cluster 1 & Cluster 2 \\
\hline 1 & $\begin{array}{l}\text { Ketersediaan helm, } \\
\text { masker, shower cap, jas } \\
\text { hujan }\end{array}$ & 7,853017 & 5,424034 & 8,129081 \\
\hline 2 & $\begin{array}{lr}\text { Terpasang } 2 & \text { spion, } \\
\text { injakan kaki, } & \text { pegangan } \\
\text { tangan,lampu } & \text { motor, } \\
\text { lampu sen } & \end{array}$ & 6,153087 & 6,870715 & 5,704964 \\
\hline 3 & $\begin{array}{l}\text { Penambahan fasilitas } \\
\text { pengaduan } \\
\text { kometar \& no telepon) }\end{array}$ & 17,34158 & 16,0492 & 20,04934 \\
\hline 4 & Penggunaan GPS & 6,59489 & 7,22961 & 6,27533 \\
\hline 5 & $\begin{array}{l}\text { Penambahan fitur foto } \\
\text { pengemudi terbaru }\end{array}$ & 7,73518 & 8,59394 & 7,22408 \\
\hline 5 & $\begin{array}{l}\text { Pemasangan tools pada } \\
\text { aplikasi yang mudah } \\
\text { dipahami }\end{array}$ & 7,73518 & 8,59394 & 7,22408 \\
\hline 7 & $\begin{array}{l}\text { Penambahan waktu } \\
\text { operasional (24 jam) }\end{array}$ & 12,892 & 14,3232 & 12,0401 \\
\hline 8 & $\begin{array}{l}\text { Ketersediaan asuransi } \\
\text { kematian \& kecelakaan }\end{array}$ & 4,28624 & 4,20686 & 4,66782 \\
\hline 9 & $\begin{array}{l}\text { Penambahan sistem } \\
\text { pengaman data konsumen }\end{array}$ & 6,00517 & 6,11662 & 6,27317 \\
\hline 10 & $\begin{array}{lrr}\begin{array}{l}\text { Perbaikan } \\
\text { komunikasi }\end{array} & \text { tata } & \text { cara } \\
\text { pelanggan } & & \end{array}$ & 11,810548 & 10,547644 & 10,584787 \\
\hline 11 & $\begin{array}{l}\text { Kelengkapan STNK \& } \\
\text { SIM/penguasaan tata } \\
\text { tertib lalulintas }\end{array}$ & 7,90282 & 8,31171 & 7,94102 \\
\hline 12 & $\begin{array}{l}\text { Driver menguasai rute } \\
\text { jalan }\end{array}$ & 3,69031 & 3,7325 & 3,88617 \\
\hline
\end{tabular}

\section{Simpulan}

Hasil Servqual dan conjoint analysis menjadi masukan dalam voice of customer dan planning matrix pada QFD. Data kombinasi atribut conjoint analysis dapat di cluster sehingga menghasilkan dua segmen, segmen keresponsifan dan empati. Hasil 
Servqual dan conjoint analysis dalam QFD memperoleh technical response sesuai dengan preferensi pelanggan sebagai upaya peningkatan kualitas. Secara keseluruhan urutan kriteria pelayanan ojek online yang menjadi kebutuhan pelanggan berdasarkan nilai kepentingan relatif dan utilitas adalah perhatian petugas ojek online, sistem informasi (aplikasi) pelayanan, waktu menunggu antar kedatangan, kelengkapan atribut motor, dan jaminan keamanan dan keselamatan. Pada penelitian ini masih memiliki kekurangan yaitu belum mempertimbangkan hubungan antar technical response dalam perhitungan kepentingan relatif sehingga diharapkan dalam penelitian selanjutnya dapat memperhitungkan hubungan antar technical response dalam perhitungan kepentingan relatif.

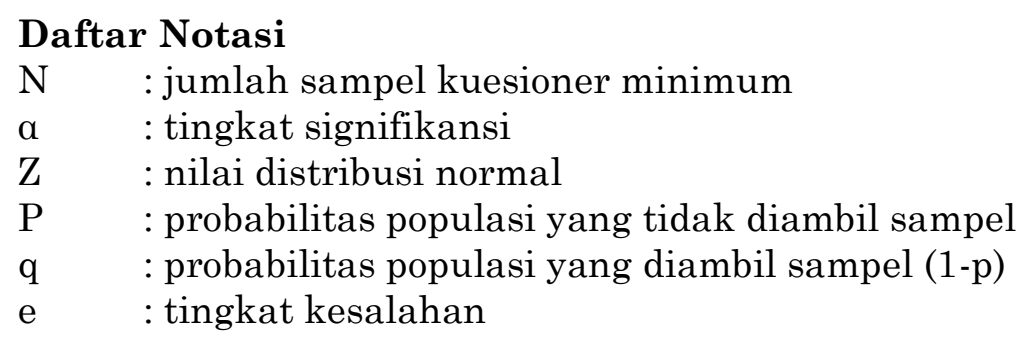

\section{Referensi}

[1] Z. Ahmad, I. Ahmed, M. M. Nawaz, A. Usman, M. Z. Shaukat, and N. Ahmad, "Impact of Service Quality of Short Messaging Service on Customers Retention; an Empirical Study of Cellular Companies of Pakistan," International Journal of Business and Management, vol. 5, p. 154, 2010.

[2] A. Hamdani and R. Lupiyoadi, "Manajemen Pemasaran Jasa," Salemba Empat, Edisi, vol. 2, 2006.

[3] L. Cohen, Quality function deployment: how to make QFD work for you: Prentice Hall, 1995.

[4] C.-H. Wang and C.-W. Shih, "Integrating conjoint analysis with quality function deployment to carry out customer-driven concept development for ultrabooks," Computer Standards \& Interfaces, vol. 36, pp. 89-96, 2013.

[5] P. E. Green, A. M. Krieger, and Y. Wind, "Thirty years of conjoint analysis: Reflections and prospects," Interfaces, vol. 31, pp. S56-S73, 2001.

[6] M. E. Pullman, W. L. Moore, and D. G. Wardell, "A comparison of quality function deployment and conjoint analysis in new product design," Journal of Product Innovation Management, vol. 19, pp. 354-364, 2002.

[7] G. M. Katz, "Practitioner note: A response to Pullman et al.'s (2002) comparison of quality function deployment versus conjoint analysis," Journal of Product Innovation Management, vol. 21, pp. 61-63, 2004.

[8] M. Chaudhuri, Bhattacharyya, A., "A combined QFD and integer programming framework to determine attribute levels for conjoint study," International Journal of Production Research, vol. 47, pp. 6633-6649, 2009.

[9] B. Li and F. Wu, "Analyzing the Variety of Customer Needs for Product Family Design by Integrating Conjoint Analysis and Quality Function Deployment," in Digital Manufacturing and Automation (ICDMA), 2011 Second International Conference on, 2011, pp. 203-206.

[10] H. Hardianawati, "Analisis Pengaruh Kualitas Pelayanan Jasa Terhadap Kepuasan Masyarakat Pengguna Transjakarta Busway Koridor 2 Pada Pemda Dki Jakarta," Jurnal Magister Manajemen, vol. 1, pp. 49-78, 2012. 
[11] S. Marliana and R. Dharmastiti, "Integrasi Servqual dan QFD untuk Meningkatkan Kualitas Layanan Angkutan Massa Trans Jogja," in Seminar Nasional Aplikasi Sains dan Teknologi-IST AKPRIND Yogyakarta, Yogyakarta, Desember, 2008.

[12] F. S. Fogliatto and G. J. da Silveira, "Mass customization: a method for market segmentation and choice menu design," International Journal of Production Economics, vol. 111, pp. 606-622, 2008.

[13] J. F. Hair, W. C. Black, B. J. Babin, R. E. Anderson, and R. L. Tatham, "Multivariate data analysis . Uppersaddle River," Multivariate Data Analysis (5th ed) Upper Saddle River, 1998.

[14] R. A. Krestonea, "Penerapan Metode Analisis Konjoin Terhadap Preferensi Konsumen Susu Rumah Tangga Untuk Pengembangan Konsep Produk Susu Cair Olahan Di Perusahaan Susu Sehat Mangli-Jember," Tesis, ITS, Surabaya, 2010.

[15] T. Fandy and G. Chandra, "Service, Quality \& Satisfaction," Andi, Yogyakarta: Andi Offset, 2005. 